\title{
RENAL FAILURE AND NEONATAL DEATH FOLLOWING SNAKEBITE DURING PREGNANCY. A CASE REPORT
}

\section{ADAM G. K. (1), HUSSEIN S. M. (2), ADAM I. (2)}

(1) Department of Obstetrics and Gynecology, University of Elgadarif, Sudan; (2) Department of Obstetrics and Gynecology, University of Khartoum, Sudan.

ABSTRACT: A thirty-five-year-old Sudanese woman (gravida 4, para 3), at 34 weeks gestational age, presented with snakebite in her right leg. Examination of the cardiovascular, respiratory, gastrointestinal, and central nervous systems revealed no abnormalities. Her blood urea was $58 \mathrm{mg} / \mathrm{dl}$; creatinine, $2.6 \mathrm{mg} / \mathrm{dl}$; whole blood clotting time, 5:35 minutes. The patient was diagnosed as having acute renal failure and was then managed conservatively. She received polyvalent antivenom serum intravenously. On the next day, she delivered prematurely and the baby passed away due to respiratory distress. There was no postpartum bleeding and the patient's clotting time was 5:30 minutes. She was discharged from the hospital after 7 days when her clinical, biochemical and hematological parameters returned to normal values without dialysis.

KEY WORDS: snake, renal, pregnancy, perinatal, Sudan.

\section{CORRESPONDENCE TO:}

ISHAG ADAM, Department of Obstetrics and Gynecology, Faculty of Medicine, University of Khartoum, P.O. Box 102, Sudan. Phone: +249 912168988 . Fax +249 18322 4799. Email: ishagadam@hotmail.com. 
G. K. Adam et al. RENAL FAILURE AND NEONATAL DEATH FOLLOWING SNAKEBITE DURING PREGNANCY. A CASE REPORT. J. Venom. Anim. Toxins incl. Trop. Dis., 2006, 12, 4, p. 654

\section{INTRODUCTION}

Approximately 125,000 deaths due to snakebites are reported every year (3). Bites by venomous snakes during pregnancy result in high fetal wastage and may cause maternal mortality, which makes such accidents an important, albeit uncommon, reality in obstetrics $(4,9,11)$. Thus, it is essential that all emergency physicians become familiar with the symptoms and treatment of venomous snakebites.

\section{CASE REPORT}

A thirty-five-year-old Sudanese woman (gravida 4, para 3) at her thirty-fourth week of pregnancy was referred from a health center to Algadarif Hospital, Eastern Sudan, with a history of snakebite in her right leg for 6 days. She was not complaining of abdominal pain, vaginal bleeding or hematuria.

Clinical examinations on presentation revealed a pulse rate of 85 beats/minute and a blood pressure of $120 / 80 \mathrm{mmHg}$. Her temperature was $37.8^{\circ} \mathrm{C}$ and respiratory rate was 25/minute. Examination of the cardiovascular, respiratory, gastrointestinal, and central nervous systems presented no abnormalities. Clinical obstetrical examination showed a fundal level of 34 weeks (which corresponded to her dates), longitudinal lie, cephalic presentation, and fetal heart rate of 145 beats/minute. These findings were confirmed by ultrasound, which also revealed no abnormalities in the liver and the kidneys. Lower limbs examination showed mild swelling below the knee of the right leg with intact peripheral pulsation. Her hemoglobin was $9.5 \mathrm{~g} / \mathrm{dl}$. Urine examination did not show hematuria. Blood urea was $58 \mathrm{mg} / \mathrm{dl}$ and creatinine, 2.6 $\mathrm{mg} / \mathrm{dl}$. The serum potassium was $4.1 \mathrm{mmol} / \mathrm{l}$; sodium, $128 \mathrm{mmol} / \mathrm{l}$; and calcium, 8 mg/dl. Whole blood clotting time was 5:35 minutes.

The patient was diagnosed as having acute renal failure and conservative management was initiated (observation and hydration). She received polyvalent antivenom serum intravenously.

On the next day, her general condition was good. Her urine output was $250 \mathrm{ml}$; urea, $113 \mathrm{mg} / \mathrm{dl}$; creatinine, $8.4 \mathrm{mg} / \mathrm{dl}$; sodium, $126 \mathrm{mmol} / \mathrm{l}$; and potassium, $4.7 \mathrm{mmol} / \mathrm{l}$. The patient complained of abdominal pain. She had normal pulse, blood pressure and respiratory rate. Vaginal examinations showed $6 \mathrm{~cm}$ dilated cervix with intact membranes and the fetal heart rate was 150 beats/minute. Five hours later, a male baby of $2.4 \mathrm{~kg}$ birth weight was delivered. After initial resuscitations, he was admitted to the intensive care unit due to his poor Apgar scores (4 at 1 and 5 minutes). The 
G. K. Adam et al. RENAL FAILURE AND NEONATAL DEATH FOLLOWING SNAKEBITE DURING PREGNANCY. A CASE REPORT. J. Venom. Anim. Toxins incl. Trop. Dis., 2006, 12, 4, p. 655

baby passed away 30 minutes later due to respiratory distress. There was no postpartum bleeding and the woman's clotting time was 5:30 minutes.

The patient was kept in the hospital for 7 days when her clinical, biochemical and hematological parameters returned to normal values without dialysis.

\section{DISCUSSION}

The patient presented with renal failure following snakebite and before receiving antivenom. High incidence (29\%) of acute renal failure has been reported after snakebite, even in specialized centers and when prophylactic measures had been taken (10). Snakebite may lead to renal failure with significant changes of the cortical and glomerular apparatus (2). Our patient received antivenom 6 days after the accident. Previous studies had suggested an association between the snakebite time interval and renal failure (10). Thus, antivenom should be available in health centers and peripheral communities rather than concentrated in referral hospitals.

The patient recovered from renal failure without dialysis. In a large series, 10\% mortality rate was reported due to renal failure after snakebite (10). The patients delivered prematurely and the babies died few hours later. Snake venom has been reported as a cause of premature labor by inducing uterine contractions (8). The stimulant action of the venom increases the frequency and amplitude of uterine contractions (7). Serious morbidity, abruptio placenta, and fetal wastage following snakebite have been previously reported in Eastern Sudan (1). There are several mechanisms which lead to fetal wastage after snakebite during pregnancy; they include direct effect of the venom on the fetus, fetal hypoxia due to maternal hypotension, venom-induced uterine contraction, pyrexia and cytokine release following tissue damage (4).

The patient received polyvalent antivenom serum by intravenous infusion, which is the mainstay of treatment for venomous bites to neutralize the venom effects. Techniques such as the use of tourniquets, incision and suction should no longer be practiced (5). The use of antivenom serum during pregnancy should balance its riskbenefit and may be lifesaving. However, anaphylaxis that may follow its administration as well as its treatment with adrenaline may jeopardize the placental circulation $(4,6)$. 
G. K. Adam et al. RENAL FAILURE AND NEONATAL DEATH FOLLOWING SNAKEBITE DURING PREGNANCY. A CASE REPORT. J. Venom. Anim. Toxins incl. Trop. Dis., 2006, 12, 4, p. 656

\section{REFERENCES}

1 ADAM I., GERAIS A.. Abruptio placentae following snakebite in a Sudanese woman. Saudi Med. J., 2005, 26, 686-7.

2 AZNAURIAN AV., AMIRYAN SV.. Histopathological changes induced by the venom of the snake Vipera raddei (Armenian adder). Toxicon, 2006, 47, 1413.

3 CHIPPAUX JP. Snakebites: appraisal of the global situation. Bull. World Health Org., 1998, 76, 515-24.

4 DUNNIHOO DR., RUSH BM., WISE RB., BROOKS GG., OTTERSON WN.. Snakebite poisoning in pregnancy. A review of the literature. J. Reprod. Med. 1992, 37, 653-8.

5 ENTMAN SS., MOISE JJ.. Anaphylaxis in pregnancy. South Med. J., 1984, 77, 402.

6 GOLD BS., BARISH RA.. Venomous snakebites. Current concepts in diagnosis, treatment, and management. Emerg. Med. Clinic. North Amer. 1992, 10, 24967.

7 OSMAN OH., GUMAA KA.. Pharmacological studies of snake (Bitis arietans) venom. Toxicon., 1974, 12, 569-75.

8 PANTANOWITZ L., GUIDOZZI F.. Management of snake and spider bite in pregnancy. Obstet. Gyn. Surv., 1996, 51, 615-20.

9 PARDAL PPO., MAZZEO T., PINHEIRO ACL.. Snakebite in pregnancy: a preliminary study. J. Venom. Anim. Toxins, 1997, 3, 280-6.

10 PINHO FM., ZANETTA DM., BURDMANN EA.. Acute renal failure after Crotalus durissus snakebite: a prospective survey on 100 patients. Kid. Inter., 2005, 67, 659-67.

11 SENEVIRATNE SL., DE SILVA CE., FONSEKA MM., PATHMESWARAN A., GUNATILAKE SB., DE SILVA HJ.. Envenoming due to snakebite during pregnancy. Trans. Roy. Soc. Trop. Med. Hyg., 2002, 96, 272-4. 